\title{
A Contrastive Study of English and Arabic Vowel Phonemes
}

\author{
Ehsan Mohammed Abdelgadir ${ }^{1}$ \\ ${ }^{1}$ Majmaah University, K.S.A. \\ Correspondence: Ehsan Mohammed Abdelgadir, Majmaah University, K.S.A. \\ Received: March 9, 2021 \\ Accepted: March 31, 2021 \\ Online Published: April 21, 2021 \\ doi: $10.5539 /$ elt.v14n5p58 \\ URL: https://doi.org/10.5539/elt.v14n5p58
}

\begin{abstract}
Consequently, the present study sheds light on a very important aspect that is a contrastive analysis of segmental vowel phonemes of both L1 and L2. As one of the problems, that is affecting the teaching/learning process of ELT. Then to clarify the different areas between the segmental vowel phonemes of Arabic and English. It also aims at making a comparative segmental analysis in the vowel phonemes of both L1 - L2, in order to shed light on the areas of difficulties. Taking into account the different forms of sounds in relation to their spellings. Also the sound systems of both languages L1 and L2. Particular the areas of common mistakes. Thus, it encourages teachers to check English pronunciation before teaching and predict problems before they happen. Also the use of advanced methods and pronunciation dictionary for (IPA). It also helps learners to master all the significant sound features and basic structural patterns. On the phonological levels, differences cause difficulties e.g. The areas of Arabic /p/ and /v/, and English front vowels phonemes /i:/-/i/- /e/- /æ/, central /ə:/- /ə/-/ /,and back/a:/-/o/-/ כ:/-/u/-/u:/ phonemes in English, they do not exist in Arabic. In addition to the English vowel /e/ which doesn't exist in Arabic. This observation can't be only linguistically, but it will also confirm by L2 learners. These theories need to be clarified in order to allow rules to be expressed. In the English language, there are 26 alphabetical letters which are totally different than their sounds. Another drawback is the alphabetical method which is intended to teach reading by means of spelling. There is no one -to- one correspondence between sounds and letters. That is to say, each different sound cannot be represented by the same letter. There are also words which are spelt differently but sound the same. Therefore, the present study concentrates on the difficulties that Learners and beginners face in using English segmental vowel phonemes. It also tries to get new methods and new ideas. This study is based on the practical experience of the writer, being specialized in English phonology, a lecturer and an author of a phonetics textbook for beginner learners who learn English as a foreign language. And as a supervisor who follows undergraduate students in the field of experience. That is, in order to find out possible remedial solutions, better suggestion and recommendations. Then follows a descriptive method to achieve this purpose. With the sample of twenty student girls. As a case study of undergraduate trainees of Majmaah Universitiy in the training field, to collect data from the subjects' real environment during talks, speeches, presentations and teaching in the Field Experience. The results were recorded to be analyzed. In particular, the areas of English vowels and diphthongs that are totally different than in Arabic.
\end{abstract}

Keywords: segmental vowel phonemes of Arabic and English, problems, analysis, solutions

\section{Introduction}

Conversely, there are words which are spelt the same but they sound differently. However, the reading and spelling skills are not closely related to each other. That is because the English alphabet has fewer letters to represent speech sounds in a way that is consistent and comparable across different languages and specially Arabic. It means that other problems appear between English sounds and spellings or the way English is written and spoken. Then sounds must be distinguished from letters. On the other hand, the vowel phonemes of English and Arabic languages are different. Accordingly, the main problems appear during the contrastive study of phonemic vowel sounds between English and Arabic. In particular the areas where English is different than learners' mother - tongue. Another part of pronunciation problem is that although teachers are the best models for their students in ELT, but most of them do not consider pronunciation as a relevant part of their education. In addition to that, the effect of graduate teachers' role in the teaching/learning process of ELT. 


\section{Review of Related Theory}

The greater the difference between two language structures, the greater is the learning problems and prospective areas of interference. Robert Lado- (1957) cites the following objectives for comparing languages. That the comparison of any two languages and cultures, discover and describe the problems that the speaker of one language will have in learning a new. On the other hand, Fries- (1945) stated that the most actual tools for teaching an L2, are those that built upon the scientific depiction of the language to be learned carefully, compared with equivalent description of L1 of the learner. Then finally the transfer theory stated that, learning difficulties were the result of interference from the old habits in the learning of new ones, Ellis- (1980). Weinreich- (1953) provides the classic definition of interference. This research was based on Error Analysis Hypothesis introduced by Larry Selinker and friends in 1970's (Light own, 2011: 79-81) in their reaction to the Contrastive Analysis Hypothesis. Linked to the related references and the strongest evidence.

As validations in the Ph.D. thesis by Ehsan Mohammed Abdelgadir- (2010) for the same domain.

\section{Methodology}

\subsection{Data Collection}

So, this research tries to investigate and identify the problems of Segmental Vowel Phonemes that face the second language students in learning English. The methodology is used for data collection through a descriptive method. As a result, it is suitable for comparing language performance after a certain program and investigating the effect of some personal factors on language acquisition. The Sample is a group of twenty student girls University, under the same classroom environments. These results which occur when transferring rules of previously acquired language to newly acquired ones. Moreover, to find out new suggestions and solutions for these problems.

\section{Analysis and Discussion}

\subsection{The International Phonetic Alphabet (IPA)}

It is certainly confusing and constitutes a heavy burden for beginner learners of the English language. For a non-native speaker a difficult part of learning how to speak English well, is a result of written spellings. For that reason, by using the (I PA) it becomes easy for the researcher to divide the English alphabet into similar sounds' group as:

1) /ei/ as in: a /ei/, j/Xei/, k/kei/

2) /i:/ as in: b/bi:/, c /si:/, d /di:/, e /i:/, g /Xi:/, p/pi:/, t/ti:/, v/vi:/

3) /e/ as in: f/ef/, h/et $\int /, 1 /$ el/, m /em/, n/en/, s/es/, x /eks/, z /zed/

4) /ai/ as in: I/ai/, y /wai/

5) /u:/ as in: /ju:/, q /kju:/, w /d $\Lambda$ blju:/

\subsection{The English Vowel Sounds}

The overall purpose of this part is to make a comparative phonological analysis, include the areas of English contrastive sounds. Then a contrastive of vowel analysis of both languages, English and Arabic. Thus, in order to clarify the areas of difficulty or common mistakes. That needs teachers' awareness and learners' attention. Tables and Chart design by the researcher are presented to summarize the different types of English spellings and pronunciation. The aim of each part is to focus on the main purpose, to trace these problematic areas. So as, to find out possible solution and suggestions.

\subsubsection{Vowel /i:/}

If learners do not have an effort into it, they will make mistakes and that can turn into bad habits. The longer learners ignore pronunciation, the more bad habit they will form. The knowledge of the human vocal systems in which vowels are articulated is very important. English uses different sounds than Arabic language. If students want to speak English well, they ought to have the habit of recognizing and pronouncing words correctly. The letter (y) is related to the English /ai/ sound in, - fight and /i/ city, busy. Whereas, long /i:/ is the sound that is closest to the letter (y) as in (leak, feet). As areas of confusion with the letter (y). It occurs initially as in eat /i:t/, medially as in clean /kli:n/ and finally as in key /ki:/). There are many spelling areas for long vowel /i:/ and it contrasts with other sounds in spellings. The table shows that this vowel is represented by different alphabetical letters which cause difficulty for beginner learners. The phoneme which is represented by the sound's letters vary from a word to another. That means we do not speak in words or even sentences the way we write. 
The features set on these charts need from teachers to let their students watch and hear how each sound is pronounced. In addition to practice the areas of different spellings or similar letters.

Table 1. Long vowel /i:/ spelling areas

\begin{tabular}{lll}
\hline$<\mathrm{ee}>$ & Meet & $/ \mathrm{mi}: \mathrm{t} /$ \\
$<\mathrm{e}>$ & Me & $/ \mathrm{mi}: /$ \\
$<\mathrm{ea}>$ & Meat & $/ \mathrm{mi}: \mathrm{t} /$ \\
$<\mathrm{ei}>$ & Being & $/ \mathrm{bi}: \mathrm{in} /$ \\
$<\mathrm{ie}>$ & Niece & $/$ ni:s/ \\
$<\mathrm{y}>$ & Quay & $/$ Ki:/ \\
$<\mathrm{i}>$ & Pizza & $/$ pi:tsə/
\end{tabular}

1) It spelt $<\mathrm{e}>$ as in me $/ \mathrm{mi}: /$ and it confuses with $<\mathrm{e}>$ in then or $<\mathrm{e}>$ in enough $/$ in $\wedge \mathrm{f} /$ etc. FL learners produce short $/ \mathrm{hi} /$ instead of long /hi:/ which is a problem of length. As a common mistake, it needs teachers' attention.

2) It spelt $<$ ee $>$ in free, tree, feet, week, which is an evidence that most of FL learners deceive by word's spelling. They are thinking that such $<\mathrm{e}>$ in he with one $<\mathrm{e}>$ is not like the double letter $<$ ee $>$ and easy for them to say feet. That is according to spelling.

3) It pelt $<$ ea $>$ as tea /ti:/, eat /i:t/, it confuses with similar spellings as: $<$ ea $>$ in head $<$ ea $>$ in wear $/$ wiə/, $<$ ea $>$ in bread/bred/ <ea $>$ break/breik/ <ea $>$ in heart/ha:t/

4) It spelt $<$ ie $>$ as in field /fi:ld/, it contrasts with $<$ ie $>$ in friend.

5) It spelt $<$ ei $>$ as in conceive /kənsi:v/, deceit /di'si:t/ and confuses with < ei $>$ in eight /eit/ and diphthong /ei/ or believe.

6) It spelt $<\mathrm{i}>$ in machine $/ \mathrm{m}^{\prime} / \mathrm{i}: \mathrm{n} /$ or police. It is similar to $<\mathrm{i}>$ as in mine $/ \mathrm{main} /$ or to $<\mathrm{i}>$ of $/ \mathrm{in} / \mathrm{etc}$.

7) It spelt $<$ eo $>$ in people /pi:pl/. It shows another different spelling areas for $/ \mathrm{i}: /$

8) It spelt $<$ oe $>$ in amoeba /a'mi:bə/. These letters are opposite to those in people. <ea $>$ in (sea /si:/) is also found in (head /hed/, early /ə:li/, heart/ha:t/ etc.). They are the cause of replacement and substitutions, (same (ea) spellings). Therefore, it is easy for graduate teachers to solve this problem by using the (IPA) for checking words' sound. Thus 'beat' /bi:t/ has only about half the length than of /i:/ in 'bead' /bi:d/. It needs more practice and drillings.

\section{i. Short vowel /i/}

It is a front vowel slightly above half-close position and short vowel sound. The lips are slightly spread. It occurs initially as in it /it/, medially sit/sit/ and finally in every /evri/. These are areas of common mistakes that commit by beginners. Because short vowel /i/ has different spelling areas which are similar to other areas. From the following table it is clear that /IPA/ is very important to clarify these confusions. This short vowel /i/ confuses with long /i:/ and diphthong /ai/ and the sound $<\mathrm{e}>$ in spellings. In this area, teachers can observe the insertion of /i/.

1) It spelt $<\mathrm{i}>$ fifth $/ \mathrm{fif} /$ /, quick $/ \mathrm{kwik} /$ which is totally different than $<\mathrm{i}>$ in mine or in police. Many students produce it as /faifth/.

2) It spelt $<y>$ in initial position as, symbol /simbl/ similar to simple, $<y>$ occurs in final position such as in city /siti/. It reflects the same letter $<y>$ in different sounds as: (say/sei/, boy, they and why). These contrastive areas need teachers' more attention.

3) It spelt $<\mathrm{e}>$ in initial position as in, enough /in $\Lambda \mathrm{f} /$ English /iY'li $\int /$, England /iYglænd/, or medial position as, pretty /priti/, needed /ni:did/. This area confuses with /e/ in word's spelling for p-e-n, p-i-n. The letter (i) and the (e) sounds (ei) as in egg. 
Table 2. Short vowel /i/ spelling areas

\begin{tabular}{lll}
\hline$<\mathrm{i}>$ & Sit & /sit/ \\
$<\mathrm{y}>$ & Pretty & /priti/ \\
$<\mathrm{ie}>$ & Ladies & /leidiz/ \\
$<\mathrm{e}>$ & Seated & $/$ si:tid/ \\
$<\mathrm{a}>$ & Private & $/$ praivit/ \\
$<$ ui $>$ & Build & /bild/ \\
$<\mathrm{o}>$ & Women & $/$ wimen/
\end{tabular}

1) It spelt $<$ ie $>$ carried / kərid/ to be (kareed), cities / sitiz/ to be <sitais $>$. There is a great similarity between long and short/i/. Many FL learners produce (sitais) depend on word's spelling for the plural of city. /i/ in final position as $<y>$ city /siti/, unlike $<y>$ in dry, boy, baby, pay.

2) It spelt $<$ ui $>$ build /bild/ which becomes /bijulid/. As a cluster final position, or (gwitar) for guitar /gi'ta:/, they are areas of common mistakes and transfer. This area is not found in Arabic language

3) It spelt $<\mathrm{a}>$ in village /vilidz/, private /praivit/, most of the students replace this $<\mathrm{a}>$ by the diphthong /ei/ and it is an area of confusion for learners. That needs contrastive drills. The $<\mathrm{e}>$ of (-Dpt) tense as in seated /si:tid/. FL learners replace the front short vowel sound to be initially (siteed). It is a problematic area that needs more attention.

4) It spelt $\langle y>$ at the end of a word, often indicates an adjective like, easy /i:zi/, heavy /hevi/ or lucky $/ \mathrm{l} \wedge \mathrm{ki} /$, it contrasts with $/ \mathrm{y} /$ spelling areas in diphthong $<\mathrm{y}>$ as in play /plei/ and $/ \mathrm{y} /$ in sky /skai/. These need more clarification for beginner learners. That is to say, the teachers' role is very important. It spelt $<\mathrm{y}>$ in rhythm / $\mathrm{riðm/,} \mathrm{lyric} \mathrm{/lirik/} \mathrm{physics} \mathrm{/fiziks/.} \mathrm{FL} \mathrm{students} \mathrm{tend} \mathrm{to} \mathrm{pronounce} \mathrm{it}<\mathrm{y}>$ according to its spelling $<$ raithm $>$. Problems of spelling in relation to sounds.

5) It spelt <ee> short vowel in coffee / $\mathrm{kofi} /$, which is similar to long /ee/ in tree /tri:/. The sounds /i/ and /e/ are areas of common mistakes, learners tend to say bit for bet and pin for pen, or /kofii/. They produce incorrect sounds. Thus, /i/ and /i:/ and /e/ need FL learners' awareness and teachers' attention.

By drilling and more listening and speaking practice.

\section{ii. Short /e/ sound and spelling areas}

/e/ is a front short vowel, intermediate between half -close and half open. The lips are made rarely spread (un rounded) to produce it. It occurs initially egg /eg/ and medially heaven /hevn/ but it does not occur in final position. It is not found in Arabic, what makes it difficult.

1) It spelt $<\mathrm{e}>$ as in hen /hen/, it confuses with long /i:/ he- and similar to short /i/ in sound. Most of learners' weak standard cause by these areas in writing and speech <pin, pen, pan $>$. It needs seeing and hearing practice.

2) It spelt $<$ ea $>$ in weather /weðə/. This spelling area confuses with long $/ \mathrm{i}$ :/ sound. The spelling areas in (meat, head, weather) cause problems for beginners, they produce non-English sounds $/ \mathrm{met} /$ for meat /wiðə/ for weather and /hid/ for head. It needs drilling practice and charts for matching exercises.

3) It spelt (a) any /eni/ and students replace it with/æ/ of banana and say <ani>. It does not exist in Arabic. The problem with this letter is that its alphabetical name is similar to, e /i/ sound. It has different spelling areas such as in the table below. If teachers know how to interpret the symbols, many of which are familiar letters of the alphabet. A dictionary can be of great help for learning pronunciation symbols. And the free online dictionary for listening.

Table 3. Short vowel /e/ spellings

\begin{tabular}{lll}
\hline$<\mathrm{e}>$ & Shed & $/ \mathrm{fed} /$ \\
$<\mathrm{ea}>$ & Bread & $/ \mathrm{bred} /$ \\
$<\mathrm{a}>$ & Any & $/ \mathrm{eni} /$ \\
$<\mathrm{ai}>$ & Said & $/ \mathrm{sed} /$ \\
$<\mathrm{u}>$ & Bury & $/$ beri/ \\
$<\mathrm{ie}>$ & Friend & $/$ frend/ \\
$<\mathrm{eo}>$ & eopard & $/$ lepəd/ \\
\hline
\end{tabular}


4) It spelt (ai) again /o'gen/ said /sed/, it confuses with diphthong /ei/ spelling areas as in plain to produce /plain/ instead of/plein/.

5) It spelt $/ \mathrm{u} / \mathrm{minute} / \mathrm{minit} /$, confuses with $/ \mathrm{i} /$ in busy, $/ \wedge /$ in but or $/ \mathrm{u} /$ of put and long schwa in turn /tə:n/ and long /u:/ in pure. It causes problems even in writing. Thus, it needs students more practice using the skills (listening, speaking and writing) and teachers have to pay more attention. This sound is not found in Arabic.

6) It spelt (ie) friend /frend/, or believe. It is pronounced as (ai). It confuses with (ie) short vowel in ladies and the long one in believe. Hence, beginners need a teachers' role in practicing this area.

7) It spelt (eo) Geoffrey / d efri/ which is similar to (eo) in people. (same spelling but different in pronunciation). FL learners pronounce (sayid for /sed/, because of the verb say). They also confuse it with the diphthongs /ei/ and short /i/ (see contrastive areas).

\section{iii. Short $/ \mathfrak{m} /$}

This vowel does not exist in Arabic. /æ/ is a front un rounded, medium or short vowel between half - open and open. The lips are slightly spread It occurs initially as in am /æm/, medially, sand /sænd/. It doesn’t occur in words' final position. Its' spelling patterns $<\mathrm{a}>$ in initial position as in add /æd/, act /ækt/, medially as in cat / kæt/, fat $/$ fæt/.

Table 4. Short vowel /æ/

\begin{tabular}{lll}
\hline$<\mathrm{a}>$ & Man & $/ \mathrm{mæn} /$ \\
$<$ ai $>$ & Plait & $/ \mathrm{plæt} /$ \\
$<$ ar $>$ & Card & $/ \mathrm{kæd} /$
\end{tabular}

1) It spelt $<$ ai $>$ plaid /plæd/ which is similar to the /e/ spelling areas as in (said) and diphthong /ei/ in wait. It causes spellings problems.

2) It spelt $<\mathrm{a}>$ as in can $/ \mathrm{kæn} /$ which confuses with another vowel sounds such as /ei/ in age or /e/ in many or /a:/ in ask (man-many) or money etc.

3) It spelt <ar $>$ as in parse, which is similar to /a:/ in arm and schwa /ə/ in particular /pə'tikjələ/. This vowel confuses with $/ \wedge /$ thus, students say (hut for hat). This is a problem of length as well as of spelling, because there are many words include the letter (a) in spelling. In addition to that, it doesn't exist in Arabic. Learners fail to master this sound.

iv. /a:/ sounds and spelling areas

/a:/ is a low back pure vowel, fully open and long. To make this sound, a learner has to drop his jaw until the lips are about $(2 \mathrm{~cm})$ apart. /a:/ has a problem of length. The differences in the vowel spelling areas are another cause of pronunciation confusions by FL learners. It occurs initially as: $n$ ask /a:sk/, medially as in fast /fa:st/ and finally far /fa:/ such as:

Table 5. Long vowel /a:/

\begin{tabular}{lll}
\hline$<$ ar $>$ & car & /ka:/ \\
$<\mathrm{a}>$ & Ask & /a:sk/ \\
$<$ al $>$ & half & /ha:f/ \\
$<$ uar $>$ & guard & /ga:d/ \\
$<$ au $>$ & laugh & $/$ la:f/ \\
$<$ er $>$ & clerk & /kla:k/ \\
$<$ ear $>$ & heart & /ha:t/
\end{tabular}

1) It spelt <ar> in arm /a: m/, argue /a:gju:/, car/ka:/, part/pa:t/. This area shows that /r/ is pronounced by most of beginner learners. Thus, it needs teachers' attention to more practice.

2) It spelt $<\mathrm{al}>$ in half $/ \mathrm{h}$ a: $\mathrm{f} /$ sometimes calf $/ \mathrm{ka}: \mathrm{f} /<\mathrm{l}>$ reflects in incorrect pronunciation by most of learners as $<$ half $>$ similar to $/ \mathrm{r} /$ semi- vowels in farm /fa:m/. These areas do not exist in Arabic.

3) It spelt (a) in fast/fa:st/, ask /a:sk/, task/ta:sk/. It clarifies the problematic areas of length between this sound and $/ æ /$. 
4) It spelt $<$ er $>$ in clerk $/ \mathrm{kla}: \mathrm{k} /$, sergeant $/ \mathrm{sa}: \mathrm{Xnt} /$. Which is also pronounced $<$ klerik $>$ and $<$ sergint $>$ by many graduate teachers of English. That it needs the habit of looking up words into dictionaries for checking.

5) It spelt $<$ ear $>$ in heart /ha:t/. This area needs teachers' attention. /r/ problematic areas of sound as $<$ hart $>$ in addition to $<$ ear $>$ part of the body /ij/. These areas reflect the confusion between sounds and spelling as in <early, heart, ear>. They are areas of common mistakes. Thus, they need teachers' effort.

6) It spelt $<$ ua $>$ in guard /ga:d/ and < au $>$ in aunt /a:nt/. This vowel confuses with the diphthong /uə/ and pronounce /guərd/. So, learners replace it with other sounds. The teacher's role is very important for clarification. These problematic areas need more listening and oral practicing.

Table 6. Short/o/ sounds and spelling

\begin{tabular}{lll}
\hline$<_{\mathrm{O}}>$ & Got & $/$ got/ \\
$<_{\mathrm{a}}>$ & Watch & $/$ wot $/ /$ \\
$<_{\mathrm{ou}}>$ & Cough & $/$ kof/ \\
$<_{\mathrm{au}}>$ & Because & $/$ bikoz/ \\
$<_{\mathrm{ow}}>$ & Knowledge & $/$ nolids/
\end{tabular}

v. Short /o/ is a back rounded vowel between open, half - open.

It is a short half open back pure vowel.

It occurs initially as in /on/ on or medially as in got/got/. It doesn't occur in final position.

1) It spelt $<_{0}>$ as in not, on, hot, confusion of spelling appears in what

2) It confuses with diphthong $/ \mathrm{ou} /$ no and the central vowel $/ \wedge /$ in money. It has the same spelling (go $/ \mathrm{g} ə \mathrm{u} / \mathrm{.no} / \mathrm{n} ə \mathrm{u} /$ ) and $<_{\mathrm{o}}>$ in do /du:/, on, they tend to reduce its length. In particular (no-not nor).

3) It spelt $<\mathrm{a}>$ in a strong form like, was /woz/, wash $/$ wol $/$, watch /wot $\int /$. It confuses with long $<_{0}>$ in ball or $/ æ /$ in man in their spelling areas. This stands evident for the degree of difficulties that are made by different word's spelling. Learners' transfer it to strange sounds.

4) It spelt $<$ ough $>$ in cough / kof/, trough /trof/, Gloucester /glostə/.

5) Hence, it is found that it confuses with $<$ ough $>$ in tough $/ \mathrm{t} \wedge \mathrm{f} /$, through $/ \theta \mathrm{ru}: /$, bough $/$ bau/ and thorough $/ \theta \wedge \mathrm{r} \partial /$. It needs teachers' attention for more clarifications and drilling practice.

6) It spelt $<$ ow $>$ knowledge /nolidz/. FL students tend to produce incorrect word (nəulig) according to $<$ ow $>$ spelling.

7) It spelt $<$ ua $>$ quarrel / kworəl/, quality /kwoləti/, quantity /kwontəti/. These areas of $<$ ou, ow $>$ are areas of common mistakes and confusion with the diphthongs /ou/ and sounds $<\mathrm{u} / \mathrm{o} />$.

8) It spelt $<$ au $>$ because /bi'koz/, Australia /os'treiliə/ using Arabic.

Thus, it shows that learners deceive by its' spelling and mix it with the diphthong /au/ <ostoralya $>$ as in their mother-tongue.

Teachers have to play the role of correcting sounds or the habit of checking up words into dictionaries. The letter $<0>$ in got /got/ is different than $<_{0}>$ in you /jכ:/. It sometimes pronounces /ou/ in final position potato /pəteitəu/. The difficulties appear in comparing spelling areas with sounds such as, $<_{0}>$ different sounds in words' initials: obey /ou'bei/ object /obdzekt/, onions / $\wedge$ njənz/, one /w^n/, observe /ob'sə:v/ orchestra / $/$ : kistrə/, outburst /autbə:st/ which need teachers' awareness and learners' attention.

vi. Long vowel / כ:/

$\supset: /$ is a back rounded long vowel. It is a long half open back pure vowel. It occurs initially as in all $/ \supset: 1 /$, medially born /bכ:n/.

In final position: more /mכ:/, long /o/ doesn't exist in Arabic. It also causes another problematic area that occur between similarities of other sounds' spelling. (corn, cow, won). It's spelling areas as in the table below: 
Table 7. Long vowel/כ:/

\begin{tabular}{|c|c|c|}
\hline$<$ or $>$ & Lord & $/ \mathrm{l}: \mathrm{d} /$ \\
\hline$<\mathrm{aw}>$ & Law & /כ// \\
\hline$<\mathrm{ou}>$ & Bought & /bכ:t/ \\
\hline$<\mathrm{au}>$ & Daughter & /dכ:tə/ \\
\hline$<\mathrm{al}>$ & Talk & $/ \mathrm{t}: \mathrm{k} /$ \\
\hline$<$ ore $>$ & Before & /bifכ:/ \\
\hline$<$ oor $>$ & Door & /dכ:/ \\
\hline$<$ our $>$ & Our & /fכ:/ \\
\hline$<$ oar $>$ & Oar & /bכ:d/ \\
\hline
\end{tabular}

1) It spelt $<$ oo $>$ door /dכ:/, floor /fl :/ which confuses with double <oo $>$ in good /gud/ and flood /fld/. These alphabetical $<00>$ letters are found in many words with totally different sounds. The teacher's role is to clarify these areas, which have totally different systems in pronunciation. They also cause a big problem for learners.

2) It spelt < ar> war /wכ:/ warm /wכ:m/ and causes a problem of confusion with short /o/ (war- was), or card, farm, arm. (spelling and sound) problems. Learners produce incorrect word for warm $/ \mathrm{wa}: \mathrm{m} /$ instead of long (o).

3) It needs teachers' awareness.

4) It spelt <or> port/pכ:t/, morning /mכ:nip/, forlorn /fə’lっ:n/.

5) It spelt <aw>, draw /drכ:/, saw/s כ:/, beginners say /hכ:/ for how /rau/ raw /rכ:/. In fact, these areas cause problems for beginner learners.

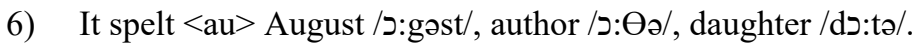

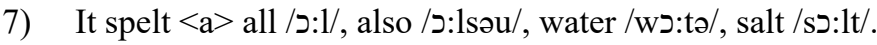

8) It spelt <oar $>$ board /bכ:d/ soar/sכ:/, roar /rכ:/.

9) It spelt (ore) more /mכ:/, before /bi'f :/ confuses with /o/.

10) It spelt <our> your /jכ:/, four /fכ:/, court /kכ:t/, source /s ::s/, course $/ \mathrm{kJ:s/.} \mathrm{FL} \mathrm{learners} \mathrm{utter} \mathrm{/fower/}$ instead of four.

This sound confuses with short $<_{0}>$ and diphthong /ou/. To clarify these areas, teachers can compare it with the Arabic $<$ > in $>$ for $<$ Kids' school and cup>. So as to solve length problem.

vii. Table 8 . /u/ sounds and spelling:- Short/u/ is a back vowel nearer to half - close than close and short (a close back pure vowel, but slightly lowered and fronted vowel)

\begin{tabular}{lll}
\hline$<_{\mathrm{ou}}>$ & Could & $/ \mathrm{kud} /$ \\
$<_{\mathrm{OO}}>$ & Good & $/ \mathrm{gud} /$ \\
$<_{\mathrm{O}>}$ & Would & $/$ wulf/ \\
$<_{\mathrm{u}>}$ & Put & $/ \mathrm{put} /$ \\
\hline
\end{tabular}

It occurs medially and doesn't occur initially or finally.

1) It spelt $<\mathrm{u}>$ as in put /put/, pull /pul/, push /pul/, butcher /but $\int \mathrm{a} /$. Sudanese learners sometimes produce /pot/ for /put/, /o/ is not found in L1.

2) It spelt $<_{0}>$ in woman /wumən/, wolf/wulf/. It needs teacher's attention.

3) It spelt $<$ oo $>$ in cook $/ \mathrm{kuk} /$, book /buk/, full /ful/, should /Jud/. $<$ ou $>$ could $/ \mathrm{kud} /$, should $/ \int \mathrm{ud} /$, beginners produce /shold/, /bu:k/ and central vowels in (yumbrella). According to letter $<\mathrm{u}>$ spelling. Teachers have to pay more attention to these areas. Therefore, to clarify the sounds in relation to their pronunciation, spellings and part of speech.

viii. Long /u:/ sounds and spelling /u:/ is a close, back, rounded, long pure vowel

It occurs initially for example ooze /u:z/, medially in fruit /fru:t/ and finally as in view /vju:/. Its spelling areas as: 
Table 9. Short vowel /u/

\begin{tabular}{lll}
\hline$<_{\mathrm{u}>}$ & Brute & $/ \mathrm{bru}: \mathrm{t} /$ \\
$<_{\mathrm{oO}}>$ & Food & $/ \mathrm{fu}: \mathrm{d} /$ \\
$<_{\mathrm{o}}>$ & Move & $/ \mathrm{mu}: \mathrm{v} /$ \\
$<_{\text {ough }}>$ & Through & $/ \theta \mathrm{ru}: /$ \\
$<_{\mathrm{ew}}>$ & Chew & $/ \mathrm{t} \mathrm{u}: /$ \\
$<_{\mathrm{ui}}>$ & Juice & $/ \mathrm{d} \mathrm{u}: \mathrm{s} /$ \\
$<_{\mathrm{oe}}>$ & Shoe & $/ \mathrm{Ju}: /$ \\
$<_{\mathrm{ue}}>$ & Sue & $/ \mathrm{su}: /$ \\
$<_{\mathrm{our}}>$ & Group & $/ \mathrm{gru}: \mathrm{p} /$
\end{tabular}

1) It spelt $<$ oo $>$ spoon /spu:n/, moon /mu:n/. It is an area of confusion. It is similar to (good, flood) in $<$ oo $>$ spelling but totally different in pronunciation. These are the areas of common mistakes. The difficulties cause by sound in relation to spelling. It needs teachers' attention.

2) It spelt $<$ oe $>$ in shoe $/ \int \mathrm{u}$ :/ and learners tend to produce /show/ for shoe.

3) It spelt $<$ o $>$ who /hu:/, to /tu:/, do/du:/ which is also similar to confuse with (how, go, of) spelling areas that reflect this difficulty. Therefore, beginners replace them and tend to use who for how.

4) It spelt $<$ ough $>$ which is the cause of difficulty for beginners. In the examples (cough $/ \mathrm{kof} /$, tough $/ \mathrm{t} \wedge$ $\mathrm{f} /$, bough /bau/. It is important to show spellings' relation with sounds in order to clarify these confusions. The word <through> is longer in writing than its' sound. / $\theta \mathrm{ru} /$ or its' spelling and pronunciation). It needs more practicing.

5) It spelt $<\mathrm{u}>$ use /ju:z/, rule /ru:1/, June /Xu:n/, rude /ru:d/. Learners contrast it with the central vowel / $\wedge /$ in but.

6) It spelt $<$ ew $>$ new /nju:/, review /ri'vju:/, contrast with know, now.

7) It spelt $<$ ue $>$ blue /blu:/, true /tru:/ cue /kju:/ sue /su:/. (sue confuses with sure / $\int$ uə/ and schwa / $\int$ wa:/ sound and schedule / $\int$ edju: $1 /$.

8) It spelt $<$ ui $>$ suit /su:t/, juice /Xu:s/. The vowels /u/ and /o/ are made by different mouth shapes. It is caused by different positions of the tongue and the lips. For example, (/o/ pot/, /u/ put, or $/ \mathrm{J}: /$ law and /u:/ in room), which cause difficulties for beginner learners. Another areas of confusion made by these vowels are their spelling areas of $<00>$ as in room, good, door etc.

ix. $/ \Lambda /$ Sound and Spelling $/ \Lambda /$ is a mid -central, un rounded short vowel. It occurs in stressed syllables initially / up $/ \wedge \mathrm{p} /$, medially as in must $/ \mathrm{m} \wedge \mathrm{st} /$ not finally.

Table 10. Short $/ \wedge /$ spellings

\begin{tabular}{lll}
\hline$<\mathrm{u}>$ & Sun & $/ \mathrm{s} \wedge \mathrm{n} /$ \\
$<_{\mathrm{o}}>$ & some & $/ \mathrm{s} \wedge \mathrm{m} /$ \\
$<_{\mathrm{ou}}>$ & country & $/ \mathrm{k} \wedge \mathrm{ntri} /$ \\
$<_{\mathrm{oO}}>$ & blood & $/ \mathrm{bl} \wedge \mathrm{d} /$ \\
$<_{\mathrm{oe}}>$ & does & $/ \mathrm{d} \wedge \mathrm{z} /$
\end{tabular}

It is not found in final position. To make this sound learners have to keep the mouth slightly open, with their lips about $(1 \mathrm{~cm})$ apart. Learners find difficulties in the pronunciation of this sound, for example, they say $<$ bodi $>$ according to $<_{0}>$ spelling instead od $/ \mathrm{b} \wedge \mathrm{di} /$. The difficulty of this sound is that it doesn't exist in Arabic. Learners replace it by /o/ as in /kom/, /som/, /bodi/ for come, some and body. It's spelling areas (u, o, ou, oo, oe).

1) It spelt $<\mathrm{u}>$ in but $/ \mathrm{b} \wedge \mathrm{t} /$, hut $/ \mathrm{h} \wedge \mathrm{t} /$ and confuses with $<\mathrm{u}>$ in cut.

2) It spelt $<_{\mathrm{o}}>$ in one $/ \mathrm{w} \wedge \mathrm{n} /$, son $/ \mathrm{s} \wedge \mathrm{n} /$, front $/ \mathrm{fr} \wedge \mathrm{nt} /$, above $/ \mathrm{\partial}$ 'b $\wedge \mathrm{v} /$, worry $/ \mathrm{w} \wedge \mathrm{ri} /$, body $/ \mathrm{b} \wedge \mathrm{di} /$, done and confuses with $<_{0}>$ in gone.

3) It spelt $<$ ou $>$ touch $/ \mathrm{t} \wedge \mathrm{t} \mathrm{f} /$, young $/ \mathrm{j} \wedge \mathrm{p} /$ country $/ \mathrm{k} \wedge \mathrm{ntri} /$, cousin $/ \mathrm{k} \wedge \mathrm{zin} /$ and also an area of confusion with $<$ ou $>$ in could $/ \mathrm{kud} /$ and $<\mathrm{ou}>\mathrm{in}$ : cough $/ \mathrm{kof} /$ or $<\mathrm{ou}>$ in bought $/ \mathrm{b} \supset$ :t/ (sound and spelling problems). 
4) It spelt $<\mathrm{oo}>$ in flood $/ \mathrm{fl} \wedge \mathrm{d} /$, blood $/ \mathrm{bl} \wedge \mathrm{d} /$ and confuses with $<$ oo $>$ in spoon, good and in floor. Which is also needs more practice and students awareness.

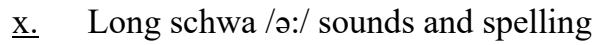

It is a mid -central, unrounded long vowel. It occurs initially in early /ə:li/. This vowel does not occur in Arabic language. In addition to that, it is represented by different letters. The following areas clarify how it can be produced. Earth /ə: $\theta /$, medially in bird /bə:d/ and finally such as were /wə:/. This short central pure vowel has different spelling areas that cause difficulty for FL learners.

1) It spelt <ir> in first /fə:st/, girl /gə:1/, skirt/skə:t/, here appears /r/ problematic areas of pronunciation.

2) It spelt <er> certain /sə:tn/, term /tə:m/, person /pə:sn/, her /hə:/.

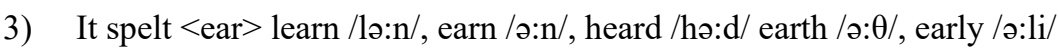

4) It spelt < our $>$ journey /d $3 \partial: n i /$ which confuses with < our $>$ in /auə/. It is an area of common mistakes. It causes problem for Sudanese learners in hearing as well as in its speech. If possible teachers have to check the correct pronunciation before saying it to their students. That is the way which is better for both of them. There are many new sounds that do not exist in our native language. The table shows it's different spelling areas.

Table 11. Long schwa/ə:/

\begin{tabular}{lll}
\hline$<$ ir $>$ & Bird & /bə:d/ \\
$<$ yr $>$ & Myrtle & /mə:tl/ \\
$<$ er $>$ & Her & /hə:/ \\
$<$ err $>$ & Err & /ə:/ \\
$<$ ear $>$ & Earn & /ə:n/ \\
$<$ ur $>$ & Turn & /tə:n/ \\
$<$ urr $>$ & Purr & /pə:/ \\
$<$ or $>$ & Word & /wə:d/ \\
$<$ our $>$ & Journey & $<$ bə:ni/ \\
\hline
\end{tabular}

\section{xi. Short schwa vowel}

$/ 2 /$ is a mid-central, un rounded short vowel.

It is commonly known as 'schwa'. It is commonly occurs in unstressed syllables and is called a (weak vowel). It is the most common vowel sound in English; most words of more than one syllable contain this vowel or unstressed syllables. It occurs initially as in apply /o'plai/, medially in contain /kən'tein/ or finally father /fa:ðə/. It is an important sound for certain grammatical markers. Learners of English need to know where schwa vowel is appropriate and where it is not. They tend to pronounce it according to the usual rule of English spellings. In consequence, FL learners have a big problem in pronouncing this vowel.

The following examples give us a guide for how to pronounce it. It's different spelling areas.

1) It spelt $<\mathrm{a}>$ in above $/ \mathrm{a}^{\prime} \mathrm{b} \wedge \mathrm{v} /$ and confuses with $<\mathrm{a}>$ in and and $<\mathrm{O}>$.

2) It spelt $<$ er $>$ in teacher $/ \mathrm{ti}: \mathrm{t} \int \mathrm{\partial} /$, entertain /intə'tein/. Then appears /r/ problematic area. In this area $<\mathrm{r}>$ pronounces before vowels as in $<$ the teacher is $>$ /ठəti:t $\int \partial r /$.

3) It spelt $<\mathrm{i}>$ possible and confuses with short vowel $/ \mathrm{i} /$ and $/ \mathrm{ai} /$.

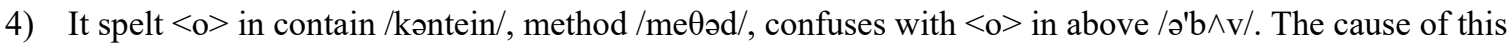
problem is the different spelling areas, which are shared in similarity by other sounds. In addition to that, this vowel is the most frequently occurring vowel in English. It does not exist in Arabic. It is not articulated with much energy. It is always associated with weak syllable. (IPA) allows learners to make connections between their spoken and written English experiences. A dictionary of pronunciation respelling is the only source of pronunciation information for most of new words. 
Table 12. Short schwa vowel /ə/

\begin{tabular}{|c|c|c|}
\hline$<\mathrm{i}>$ & impossible & /im'posəbl/ \\
\hline$<\mathrm{e}>$ & Gentleman & /im'posəbl/ \\
\hline$<_{0}>$ & Oblige & /a'blaidz/ \\
\hline$<\mathrm{u}>$ & Suppose & /sə'pəuz \\
\hline$<$ ar $>$ & Particular & /pə;tikjələ/ \\
\hline$<$ er $>$ & Mother & /m^ðə/ \\
\hline$<$ ous $>$ & Famous & /feiməs/ \\
\hline$<$ or $>$ & Color & $/ \mathrm{k} \wedge \mathrm{\partial} /$ \\
\hline$<$ ough $>$ & Thorough & /Orə/ \\
\hline
\end{tabular}

Another problem is that the quality of this vowel is not always the same. Learners of English need to know schwa spelling areas in order to learn how to pronounce it.

5) It spelt $<\mathrm{u}>$ in suppose, success, which is similar to $<\mathrm{u}>$ in but.

6) It spelt $<$ ar $>$ particular /pə'tikjələ/. It confuses with long $<\mathrm{a}>$.

7) It spelt $<$ or $>$ doctor $/$ doktə/. It mixes with short and long $<_{0}>$.

8) It $<$ ure $>$ in measure /mezə/, picture. It confuses with /uə/.

9) It spelt $<$ ough $>$ in borough $/$ brə/, thorough $/ \theta \mathrm{r} ə /$.

10) It spelt with any of the five vowel letters (o, $u, a, i, e)$.

\subsubsection{Diphthongs}

A diphthong is a glide from one vowel sound to another within one syllable (a union of two vowel sounds). The whole glide acts like one of the long simple vowels. So it is shorter before strong consonants and longer before weak ones. The English diphthongs are of three groups, those which end in ju:/ (au, ou), with /i/ (ei, ai, Ji) and those which ends in schwa /ə/ (iə, uə, eə). Because it doesn't occur in Arabic. Each diphthong sound is presented by different spellings.

The table below shows the different spelling areas. The easiest way for beginners to grasp it, by stating with the alphabetical letters, a /ei/, j / $\mathrm{b}$ ei/ and $\mathrm{k} / \mathrm{kei} /$.

4.2.2.1 A diphthong /ei/ is a mid f-ront, un rounded glide. The lips are spread. It occurs initially in ate /eit/, medially in great/greit/ and finally as in stay/stei/. It's spelling areas as:

1) It spelt $<\mathrm{a}>$ in ache /eik/, face /feis/, gate /geit/, date /deit/, made /meid/, came $/ \mathrm{keim} /$, table $/$ teibl/ $<\mathrm{a}>$ spelling is an area of confusions. It is the first alphabetical letter in English. It is similar to many English sounds' spelling areas.

Table 13. Diphthong /ei/ sound and spelling

\begin{tabular}{lll}
\hline$<\mathrm{a}>$ & Late & /leit/ \\
$<$ ei $>$ & Eight & /eit/ \\
$<$ ay $>$ & Way & /wei/ \\
$<$ ey $>$ & They & /dei/ \\
$<$ ea $>$ & Great & /greit/ \\
$<$ ai $>$ & Wait & /weit/
\end{tabular}

This is an evident why learners deceive by their spellings to produce incorrect words. So, they have to be aware of this sound.

2) It spelt < ai > aim /eim/, rain /rein/, wait /weit/, raise /reiz/.

It confuses with $<$ ai $>$ in plaid /plæd/, said /sed/ and the diphthong /ai/. Thus, beginners produce $<$ ai $>$ sound to substitute /ei/. That is according to spellings.

3) It spelt < ay $>$ pay /pei/, way /wei/, pray /prei/, then confuses with $<$ y $>$ dry and produce $<$ ai $>$ sound, such as /prai/ and /pai/ or may etc. 
4) It spelt $<$ ey $>$ they /dei/, which is similar to $<\mathrm{y}>$ in dye /dai/, city /siti/ and also confuses with /i/ in /di/ for they, it confuses with /e/ and /i/.

5) It spelt $<$ ea $>$ great /greit/, break /breik/. This area is similar to long /i:/. As a consequence, students produce /grit/ for great which is similar to $<$ ea $>$ in treat/tri:t/ and they also confuse it with $<$ ea $>$ in thread / $\theta$ red/

6) It spelt <eight> in weight /weit/. It replaces by /i:/ /wi:t/.

7) It spelt $<$ aight $>$ in straight $/$ streit/ pronounce by learners as $<$ street $>$.

It always pronounces rather short and then confuses with /e/ and say /stret/ FL learners utter/tek/ for /teik/ or made, make, sake and for gate (get).

Another problems of diphthongs which commit by students in this area is to shorten the sound when no short is needed and vice versa. FL learners pronounce it similar to /ai/ as in high and produce non - English words. These areas explain and provide insights into similarities and differences between language structures. That is to say, sounds form a strongly closed system in comparison to higher units $\mathrm{m}$ such as words and sentences.

For that reason more descriptions and comparison is made.

\subsubsection{Diphthong/au/}

/əu/ is a mid, back rounded glide. It occurs initially, as in over /əuvo/, medially in stone /stəun/ and finally in go /gəu/, know /nəu/. To pronounce /ow/ sound, FL students have to open the lips about $(1.3 \mathrm{~cm})$ apart round them into a circle. This vowel often confuses with $/ \mathrm{J} / /$ as in bought /bכ :t/ and boat/bout/. It is a strange sound for learners.

1) It spelt (o) in wrote /rout/, over /ouvə/, old /ould/.

2) It spelt (oa) in road $/ \mathrm{r}$ rud/ coat $/ \mathrm{k} ə u t /$. It is pronounced short.

3) It spelt (oe) toe /təu/, joe /ḑəu/, goes /gəuz/ (ou) soul/səul/ shoulder/fəuldə/. Students have problems of length in this area.

4) It spelt $<$ ou $>$ in though /ठəu/, dough /dəu/. They produce short $<_{0}>$

5) It spelt (ow) owner/əunə/, window /windəu/, sew /səu/, know /nəu/.

Table 14. Diphthong/əu/

\begin{tabular}{lll}
\hline$<_{0}>$ & Go & $/$ gəu/ \\
$<$ oa $>$ & Goat & $/$ gəut/ \\
$<$ ou $>$ & Soul & $/$ səul/ \\
$<$ ow $>$ & Snow & $/$ snəu/ \\
$<$ oe $>$ & Foe & $/$ fəu/
\end{tabular}

The glide begins from slightly below the half - close front position and moves in the direction of $|\mathrm{i}|$, there being a slight closing movement of the lower jaw. In consequence, student tend to use /o/for different sounds such as go, other, our not etc. FL teachers have to pay more attention to these areas.

\subsubsection{Diphthong/ai/}

It is a low, front un rounded glide. The lips change from a neutral to a loosely spread position. It occurs initially either /aiðə/, medially in night /nait/ and finally in apply /ə'plai/, my /mai/. It's spelling sound and spelling.

1) It spelt $<\mathrm{i}>$ high /hai/, child /t $\mathrm{t}$ aild/, like /laik/, which is similar to short vowel /i/ as in tin and FL beginners use to replace it with /i/ and produce /lik/ for like. It is an area of common mistake for beginners.

2) It spelt $<y>$ in sky /skai/. It pronounces /ski/ instead of /skai/.

3) It spelt $<$ igh $>$ right $/$ rait/, might $/$ mait/.

4) It spelt $<$ ie $>$ lie /lai/, tries /trais/ which confuses with trees.

5) It spelt $<$ ye $>$ eye $/ a i /$, (eye+I+/ai/), confuse with /e/ and /i/ sounds.

6) It spelt $<$ ei $>$ neither $/$ naiðə/, loud /laud/. 
Table 15. Diphthong /ai/

\begin{tabular}{lll}
\hline$<\mathrm{i}>$ & Bite & /bait/ \\
$<$ igh $>$ & might & /mait/ \\
$<\mathrm{y}>$ & Buy & /bai/ \\
$<$ ie $>$ & Lie & /lai/ \\
$<$ ei $>$ & either & /aiðə/ \\
$<$ eight $>$ & height & /hait/ \\
$<$ ye $>$ & Dye & /dai/
\end{tabular}

FL learners used to replace /ai/ with short vowel /i/ as in /find/ for /faind/ and produce incorrect sounds. It contrasts with diphthong /ei/

\subsubsection{Diphthong/au/}

/au/: This is a combination of sounds $/ \mathrm{a} /$ and $/ \mathrm{u} /$. It begins with/æ/ setting the lips $(1.5 \mathrm{~cm})$ apart, then glide into /ow/ forming a circle as how. It is a low, unrounded glide. It begins at a point between the back /ai/ front open positions and moves in the direction of $/ \mathrm{u} /$. The lips changes from open to a weakly rounded position. It occurs initially as in our /auə/, medially found /faund/ and finally cow $/ \mathrm{kau} /$. . The contrastive area of this vowel clarifies its different spelling letters. The sounds in words now, new, know are produced incorrect. $<$ no $>$ for both $<$ now, no $>$. All vowels and diphthongs cause problems for learners in speaking and listening or even writing.

Table 16. Diphthong /au/ spellings

\begin{tabular}{lll}
\hline$<$ ou $>$ & Noun & /naun/ \\
$<$ ow $>$ & How & $/$ hau/ \\
$<$ ough $>$ & Bough & $/$ bau/
\end{tabular}

1) It spelt $<$ ow $>$ now $/ \mathrm{nau} /$. It is another area of common mistakes.

2) It spelt $<$ ou $>$ loud /laud/. It confuses with the diphthong /ou/ and /u/ vowel in could, or bought and /o/ in cough or /u:/ in through and <ough> as in bough, plough, drought. It confuses with /o/, /ou/. That most of learners produce $<$ fowund $>$ for $/$ faund/.

\subsubsection{5/כi/}

The /oiy/ sound is a combination of two sounds beginning with /o/ and ending in /iy/. The lips set about $(1.3 \mathrm{~cm})$ apart, begin in a circle.

1) It spelt $<$ oy $>$ as in, joy / $\mathrm{d} \zeta \mathrm{j} /$, toy $/ \mathrm{t} \supset \mathrm{i} /$. It confuses with $<0<$ body.

2) It spelt $<$ oi $>$ in voice /v כis/, enjoy /indz $\supset i /$. It is not exist in Arabic.

The spoiled boy destroyed Floyd's joy. Roy's toys are noisy. Troy's ploy was foiled. This area is difficult for learners. They tend to produce /bowil/ for boil. It needs teachers' awareness.

\subsubsection{Diphthong /ia/}

It is a diphthong that begins like /i/ and ends like /ə/. The lips are spread to open. It occurs initially idea /idiə/, medially, fierce /fiərs/ and finally as in: spear/spiə/, here/hiə/, near/niə/, ear/iə/ which is similar to Arabic words (ها هي) which have diphthongs very similar to /iə/.

1) It spelt $<$ ere $>$ here $/$ hiə/. The different spellings are the cause of the problems here. The word $<$ here $>$ confuses by learners with $<$ there $>$.

2) It spelt $<$ ea $>$ hear/hiə/which has the same sound as $<$ here $>$. It similar to $<$ ea $>$ spellings such as, in heart /ha:t/, heard /hə:d/, head/hed/, heat /hi:t/.

3) It spelt $<$ eer $>$ beer / biəl/, dear, deer /diə/. It confuses with long /i/ spelling areas of $<$ ea $><$ ee $>$ and long schwa $<$ learn $>$ (common mistakes).

Table 17. Diphthong /iə/

\begin{tabular}{lll}
\hline$<$ ere $>$ & Here & $/$ hiə/ \\
$<$ ea $>$ & Clear & $/$ kliə/ \\
$<$ eer $>$ & Deer & $/$ dia/ \\
\hline
\end{tabular}


These areas do not exist in Arabic. Then most of learners transfer, well-known sounds by the new ones. Thus, results of the sound in relation to its spellings, cause errors.

\subsubsection{Diphthong /eə/}

The glide of the diphthong /ea/ begins in the half- open front position /e/ and moves in the direction of the open variety of $/ \mathrm{a} /$. By these contrastive areas, teachers can predict which of these sounds would be easy to learn; and which would be difficult and lead to errors. Therefore, graduate teachers are able to learn the symbols and their exact sounds, and how to say them in different combinations. They will be able to find the pronunciation of any word in the dictionary.

Table 18. Diphthong /eə/ sound and spelling

\begin{tabular}{lll}
\hline$<$ ere $>$ & There & $/$ /eə/ \\
$<$ yer $>$ & Player & $/$ pleə/ \\
$<$ re $>$ & Cure & $/$ keə/ \\
$<$ air $>$ & Pair & $/$ peə/
\end{tabular}

To make this sound, keep the jaw halfway open. The lips are $(1.3 \mathrm{~cm})$ apart. Tense the lips and form a wide, downward smile. It occurs initially as in air /eə/ medially in variation, /veəreifən/, finally as in pair /peə/, chair $/ \mathrm{t} \int \mathrm{e} /,<$ were $/$ weə/, where /wea/>. It does not exist in Arabic.

1) Its spelt $<$ are $>$ in care $/ \mathrm{keə} /$, share $/$ e eə/, stare $/$ steə/ square $/$ skweə/.

2) It spelt $<$ air $>$ in repair /ri'peə/ air /eə/. FL learners produce (er).

3) It spelt $<$ ere $>$ in there /ðeə/, where /weə/, which is similar to /iə/ spelling.

4) It spelt $<$ eir $>$ their /ðeə/ which confuses with there /ðeə/.

Students replace this sound by $<$ ¿eir $>$ to produce incorrect words.

5) It spelt $<$ ar $>$ scarce /skeəs/, which is similar to /uə/ in spelling.

\subsubsection{Diphthong/uə/}

/uə/ is a glide from / $\mathrm{u} /$ position to the schwa /ə/. It occurs medially in fewer/fjuə/ and finally such as sure/Juə/.

1) It spelt $<_{\mathrm{OO}}>$ in poor /puə/ which is part of $<\mathrm{oO}>$ problems as in door, good, spoon etc.

2) It spelt $<$ ure $>$ in cure $/ \mathrm{kjuə/}$, pure /pjuə/, sure / ù/.

Table 19. /uə/ sound and spelling

\begin{tabular}{lll}
\hline$<$ oo $>$ & Poor & /puə/ \\
$<$ ure $>$ & Pure & /pjuə/ \\
$<$ oer $>$ & Doer & $/$ duə/ \\
$<$ wer $>$ & Fewer & $/$ fjuə/ \\
$<$ ou $>$ & Tourist & $/$ tuərist/
\end{tabular}

It confuses with $/ \mathrm{u} /$ such as put and $<_{0}>$ in pure vowels' areas which produce shorter than diphthongs.

3) It spelt $<$ our $>$ tourist, your, tour purely /pjuəli/, you're /juə/.

4) It spelt $<$ oer $>$ doer $/$ duə/. FL learners pronounce it $<$ dowr $>$.

5) It spelt $<$ wer $>$ fewer $/$ fjuə/. Other problematic areas of $/ \mathrm{r} /$.

6) It spelt $<$ ou $>$ tourist /tuərist/.

This sound doesn't occur in Arabic. So, it caused difficulty for FL learners. Contrastive English vowel sounds:

The main purpose of this contrastive analysis is to differentiate between these sounds and their spellings in order to avoid replacement and confusion. By using (IPA), words become easy to pronounce. 


\subsubsection{Front Vowels Contrastive Areas}

There is no one-to-one correspondent between sounds and letters. That means there are words which are spelt the same but sounds differently such as: read /ri:d/ (infinitive) and read /red/ (past tense).

1) /i:/ and /i/ often confuse: /it/ for eat, or ease for is -seat for sit. These areas are similar to Arabic, but they need more practice.

2) /i/ and /e/ misuse, because of the similarity in their spellings.

That /pin/ uses for /pen/. /e/ does not exist in Arabic, teachers have to pay more attention and solving students' problems. The table below reflects the areas of contrast between the front vowels and the size of difficulties that learners face in these areas: IPA- type- symbol are a guide to the sounds' pronunciation. These symbols provide little help for learning the spelling. That is because English has many alphabetical letters resulted from many complicated sound changes.

These areas are the cause of difficulties for many students, in writing and listening. In particular the /i/, /e/ sounds. They produce pin for pen and pan for pain.

Table 20. /i:/, /i/, /e/, /æ/

\begin{tabular}{llll}
\hline /i:/ & /i/ & $/ \mathrm{e} /$ & $/ \mathfrak{m} /$ \\
$\mathrm{feet} / \mathrm{fi}: \mathrm{t} /$ & $\mathrm{fit} / \mathrm{fit} /$ & $\mathrm{fed} / \mathrm{fed} /$ & $\mathrm{fat} / \mathrm{fæt} /$ \\
$\mathrm{deed} / \mathrm{di}: \mathrm{d} /$ & $\mathrm{did} / \mathrm{did} /$ & $\mathrm{dead} / \mathrm{ded} /$ & $\mathrm{dad} / \mathrm{dæd} /$ \\
$\mathrm{read} / \mathrm{ri}: \mathrm{d} /$ & $\mathrm{rid} / \mathrm{rid} /$ & $\mathrm{red} / \mathrm{red} /$ & $\mathrm{rat} / \mathrm{ræt} /$ \\
\hline
\end{tabular}

Teachers can create oral reading exercises to check the problematic areas of difficult sounds such as $/ \mathrm{i}: /, / \mathrm{i} /$ or $/ \mathrm{i} /$, /e/. Therefore, to help students improve their standard. These kinds of contrastive sounds help both teachers and learners

Six sheep were sick on the ship. $<$ ship, shape, shop, sheep, chip $>$

She's as thin as he is. The areas of contrast $<$ then, thin, than ten $>$

Jim eats cheap chips. $<$ mean, men, moon, man $>$. Pan, pin, pain, pen.

Please freeze the peas. <piece, pass, peas $>$

4.2.3.1 Front and Central Vowels Contrast/ə:/, / //, /১:/, /æ/, /a:/, /e/

These word pairs clarify the difference between sounds and their spellings. head /hed/, heart /ha:t/, lead /li:d/, learn /lə:n/. (ea) alphabet letters.

It is clear that they have different sounds, but the same $<$ ea $>$ spelling letters. Their different sounds and spelling patterns. May teachers be aware of attempting to transcribe or pronounce some sounds of language.

The pronunciation case needs special attention. That's to solve problems. The transcription provides better help. The $/ \mathrm{r} /$ problems increases in long schwa, such as (brid) for bird (beard - bread), thread and third or the (o) of word, it is produced like board and the (o) in body, come, country. These are the areas of pronunciation respelling problems. It needs from teachers to pay more attention.

Table 21. /ə:/,/^/,/১:/, /æ/, /a:/, /e/

\begin{tabular}{|c|c|c|c|c|}
\hline /ə:/ & $/ \wedge /$ & /כ:/ & /a:/ & /e/ \\
\hline turn /tə:n/ & $\operatorname{turn} / \mathrm{t} \wedge \mathrm{n} /$ & torn $/ \mathrm{t} \supset: \mathrm{n} /$ & $\operatorname{tarn} / \mathrm{ta}: \mathrm{n} /$ & ten $/$ ten/ \\
\hline bird /bə:d/ & bud $/ \mathrm{b} \wedge \mathrm{d} /$ & board /bכ:d/ & bard /ba:d/ & bed /bed/ \\
\hline burn /bə:n/ & bun $/ \mathrm{b} \wedge \mathrm{n} /$ & born /bכ:n/ & barn /ba:n/ & ben /ben/ \\
\hline pert /pə:t/ & putt $/ \mathrm{p} \wedge \mathrm{t} /$ & port /pכ:t/ & part/pa:t/ & pet /pet/ \\
\hline
\end{tabular}

FL beginner learners tend to make errors. In particular $/ \mathrm{s} /$ and $/ \mathrm{z} /$ sounds.

They misuse some areas of sounds which need more practice such as I guess the car needs gas. The head of the group had left. Two men or one man. The pen is by pan. They said it was sad.

/ai/, /i/

The $/ \mathrm{i} /$ in thin $/ \theta \mathrm{in} /$ is a short vowel which has a totally differ sound than the /i/ in "divine" /divain/ which is a diphthong /ai/. The greatest difficulties that FL learners face are in spelling and pronunciation of the sound /i/. In 
addition to the letter /e/ which is a long vowel as in he /hi:/ and short in /pen/. These examples show clearly the contrastive areas that FL learners face. Thus teachers have to prepare more drills for more practice in both spelling and pronunciation. The researcher uses phonetic symbols as used in dictionaries to provide learners with the exact pronunciation of words, because in phonetic script each different sound is represented by a different symbol. Thus, it reflects the importance of teachers' role.

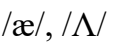

The fact is that these sounds cause problems in their pronunciation as well as spelling. They become clear by using intensive drills as in this example "The bat can hear but not see". These areas are very important for pupils. The cap is by the cup. Teachers have to help learners with more drills. The cat will cut the string. The use of /IPA/ is very important to clarify it. That team has a lack of luck. I ran /ræn/ and I will run again, (under the rain). FL learners can practice using (read the odd sound).

/o/, /æ/

The contrastive areas help teachers to know the student's weak points. For example read the following sounds: Ann is on the phone. It's too hot to wear a hat.

That insect is not a gnat. Try not to rock the rack.

Pat made a pot of tea. Ron and I ran.

$/ 0 /, / \Lambda /$

FL learners also confuse between letters and phonemes for example

The English letter (u) in the words $<$ put, but $>$. The first $/ \mathrm{u} /$ in $/$ put/ and the second is $/ \Lambda / / b \Lambda t /$ in relation to their phonemes (p, b).

Sometimes $/ \mathrm{u} /$ put substitutes with /o/ of pot. It needs teachers' attention in problems; solving (contrastive drills) as: My boss takes the bus. Can you hang a big Hog?

It was hot inside the hut. I could not crack the nut.

What color is the collar? What is also need teachers' awareness?

$/ \mathrm{J} /, / \mathrm{L} /$

These vowels are not exist in English. Then the difficulties become clear in these contrastive areas, which have a $<\mathrm{oo}>$ in their spellings and pronounced as $/ \mathrm{J}: /$ in floor /fl $: /, / \wedge /$ of flood $/ \mathrm{fl} \wedge \mathrm{d} /$, good /gud/ poor /puə/ or $<$ dawn $/$ daun/, done $/ \mathrm{d} \wedge \mathrm{n} /$, gone $/ \mathrm{gon} />$ that have different sounds. After learning each sound, students have to compare difficult sounds. They need more listening drills and oral reading practice.

The criminal was caught $/ \mathrm{k} \supset: \mathrm{t} /$. The prices were $\mathrm{cut}$. What have you done? I woke up before dawn. The shirt has a dirty cuff. She has a cough $/$ kof $/$.

$/ \mathrm{u} /, / \mathrm{\Lambda} /$

These are also other areas of pronunciation contrast. $<$ book, buck $>,<$ look, luck $>,<$ took, tuck $>$ or (god, good, goods). FL learners use to replace them and produce /u/ with a long vowel /bu:k/ according to the $<$ oo $>$ length in book. So, $<\mathrm{u}>$ and $<00>$, $<0 \mathrm{ow}>$ are alphabetical letters which cause problems for beginner learners of English.

Moreover, the problems of pronunciation of many words include the $<00>$ spellings such as the long vowel $/ \supset$ :/ in $<$ floor $/ \mathrm{fl}$ :/ or the long vowel $/ \mathrm{u}: /$ in $<$ fool /fu:l/>, short vowel $/ \mathrm{u} /$ in look $/ \mathrm{luk} /$, and the central vowel $/ N /$ in $<$ flood /fl $\Lambda \mathrm{d} /$. Thus, one of the main important points is the teacher's role. FL learners need more intensive contrastive drills to master these areas. In particular the minimal pairs for example, take a good look. Tuck in your shirt. I took the shirt. Is a dollar a buck? Did you read a book? I wish you luck.

\subsubsection{Central and Back /u:/, /u/, / / /, / :/ Contrastive Areas as /১:/,/ə:/}

In these words the letters (ir, or) are long vowels, the first is a back vowel and the second is a central vowel. Their contrastive areas appear in these word pairs <firm /fə:m/, form /f $: \mathrm{m} />$, <were, wore $>$, <shirt, short $>$. These sounds are not found in Arabic. The difficulties appear in these contrastive areas of sound and spellings. They clarify the type of difficulties that learners face in these area. These differences cause difficulties. The greater the differences between two systems, the greater the learning problems and potential areas of interference are. The comparison between sounds and their spellings make it easy to know the cause of this transfer. (initial, special, solution etc.)

Teachers can discover and describe the problems that the speaker of one language will have in learning L2. 
Table 22. /u:/, /u/, /^/, / כ:/

\begin{tabular}{llll}
\hline$/ \mathrm{u}: /$ & $/ \mathrm{u} /$ & $/ \wedge /$ & $/ \supset: /$ \\
shoe $/ \int \mathrm{u}: /$ & should $/ \int \mathrm{ud} /$ & shut $/ \int \wedge \mathrm{t} /$ & $\operatorname{door} / \mathrm{d}$ :/ \\
tool $/ \mathrm{tu}: 1 /$ & took $/$ tuk/ & stuck $/ \mathrm{st} \wedge \mathrm{k} /$ & floor $/ \mathrm{fl}$ :/ \\
you /ju:/ & put $/$ put/ & but $/ \mathrm{b} \Lambda \mathrm{t} /$ & your $/ \mathrm{j}$ :/ \\
\hline
\end{tabular}

\subsubsection{Contrastive English Vowels and Diphthongs}

\subsubsection{Contrastive /i:/, /i/, /ei/ and /e/}

He met his mate there. There is a meeting in the club. Please omit it. You'll get wet if you don't wait. Wheat is better than sweet. I will get the gate. Greet with great respect. Pay the debt by that date. Sit on that seat and take a set of books. Don't let them be late. He lit the fire. Let him lay down. English has more vowels than Arabic. They are seven short and five long. The contrastive areas of sounds are areas of common mistakes. Learners tend to produce incorrect sounds and substitute many of them Teachers have to know the cause for these difficulties, in order to help learners. These problems become clear by comparing these sounds with their spellings (wheat, wit, wait, wet or white). Moreover, teachers as well as learners have to pay more attention towards solving these difficulties. Viewed from the point of view of foreign language learning, a phonemic symbol should also be easily learned and accepted by the learner.

Late, light, claim, climb, way, white, wheat, let, lane, line, lien, etc.

Contrastive exercises for practicing are the solution for these problematic areas.

Learners need teachers' help and advice.

These table shows the areas of contrastive spellings and sounds.

Table 23. /i:/, /i/, /ei/

\begin{tabular}{llll}
\hline /i:/ & /e/ & /i/ & /ei/ \\
\hline feel /fi:l/ & fell /fel/ & Fill /fil/ & fail /feil \\
meet /mi:t/ & met /met/ & mid /mid/ & made /meid/ \\
keep /ki:p/ & kept /kept/ & kick /kik/ & cake $/ \mathrm{keik} /$ \\
\hline
\end{tabular}

As a result of differences, learners tend to use smaller numbers to cover the amount of English vowels. The common mistakes that appear in these areas are, in lengthening the short vowels when no length is needed or vice versa, for example, /kofi:/ for /kofi/. Anyhow vowels must be learned by listening and imitating. There is no single letter which always stands for each vowel. FL learners are also shorten the diphthongs as /pepa/ for /peipə/.

4.2.4.2 Contrastive /ou/, /o:/, / :/, /o/, / / /, /ou/, /o/

In fact, this are problems of sound quality as in a diphthong /ou/ and the length of a short back vowel /o/ as in word pairs $<$ go /gəu/, got /got/ $>$ FL learners tend to produce /no/ for /nəu/ or /windo/ for /windəu/. These are kinds of common mistakes that need more practice.

He is John and she is Joan. There was a rod on the road. The first bird gets the worm. I won't go unless I want to. The note is not there. The coat is on the cot. This table shows the areas of contrast between sounds, to clarify the different sounds in relation to their spellings and pronunciation. These areas do not found in Arabic. Learners find it difficult to pronounce and to write. Therefore, they transfer sounds that they don't know.

Table 24. /ou/, /ə:/, / :/, /o/, /N/

\begin{tabular}{|c|c|c|c|c|}
\hline /ou/ & /ə:/ & /כ:/ & $/ 0 /$ & $/ \wedge /$ \\
\hline bone /bəun/ & burn/bə:n & born /bつ:n/ & gone/gon/ & none $/ \mathrm{n} \wedge \mathrm{n} /$ \\
\hline woke /wəuk/ & work/wə:k/ & walk /wכ:k/ & what/wot/ & one $/ \mathrm{w} \wedge \mathrm{n} /$ \\
\hline
\end{tabular}

This table shows sounds that do not occur in Arabic.

4.2.4.3 Contrastive /ou/, /au/, / :/, /ə:/, /^/

Some FL learners pronounce these word pairs similarly $<$ found $/$ faund/, phoned /found/>. I found out who phoned. $<$ Hose, house $>$ 
The hose is by my house. How, hoe. How do I hoe the garden. Now I know. I heard her journey was worth the worry. The mother won some of the money, but not enough. Are you allowed to speak aloud? These contrastive areas show the differences between spellings and sounds. The table compares vowels and diphthongs.

Table 25. /ou/, /au/, / כ:/, /ə:/

\begin{tabular}{|c|c|c|c|c|}
\hline /ou/ & $/ \mathrm{au} /$ & /】:/ & /০:/ & $/ \wedge /$ \\
\hline dome /dəum/ & down /daun/ & door /dכ:/ & dare /də:/ & duck $/ \mathrm{d} \wedge \mathrm{k} /$ \\
\hline home /həum/ & house /hauz/ & hall /hつ:1/ & burn /bə:n/ & dull $/ \mathrm{d} \wedge \mathrm{l} /$ \\
\hline
\end{tabular}

4.2.4.4 Contrastive /u/, /u:/, /uə/, /əu/, /au/

Look in the cook book for a good pudding. The news is too gloomy. It blooms soon, in June. It should be good wool. A few beauties were in the picture. Show Joe the snowmobile. Oh no, don't go. This is a universal truth. We found our flower downstairs. FL learners confuse these areas.

Table 26. /u/, /u:/, /uə/, /ou/, /au/

\begin{tabular}{lllll}
\hline$/ \mathrm{u} /$ & $/ \mathrm{u}: /$ & /uə/ & /əu/ & $/ \mathrm{au} /$ \\
\hline good /gud/ & new /nju:/ & newer /njuə/ & know /nəu/ & now /nau/
\end{tabular}

They tend to replace each sound by another. The table below reflects the problematic areas that non-Arabs learners face in learning English.

The differences between these sound systems lead the researcher to select these contrastive areas in order to show how they differ from the learners' native language. In addition to what type of problems are caused by these differences. These tables clarify the different spelling in relation to sounds.

Table 27. /u:/, /iə/, /eə/, /ou/, /uə/

\begin{tabular}{lllll}
\hline too /tu: $>/$ & tear $/$ tiə/ & stare $/$ steə/ & stone $/$ stəun/ & your $/$ juə/ \\
pew /pu:/ & peer /piə/ & air /eə/ & poor /puə/ & go /gəu/
\end{tabular}

These areas of sounds contain long vowels in similar position. Learners find them difficult in their pronunciation. They need clarification and more drillings. Both teachers and learners have to be aware of.

\subsection{Arabic Vowels}

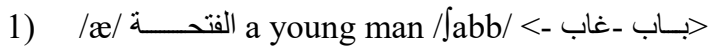

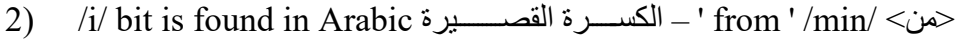

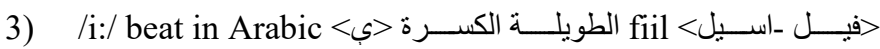

4) /e/ bet in Arabic is not found

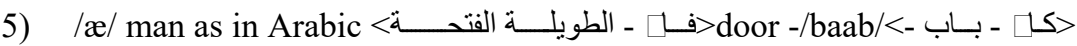

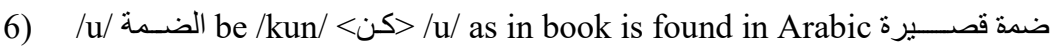

7) /uu/ whale /huut/ >حوت>>>

8) $/ 2 /$ as in about, does not exist in Arabic

9) Long vowel /:כ/ doesn't exist in Arabic and short /o/

10) /aw/ if -or /law/ $<$, $>$

11) /ay/ in order to $>$

ii - high front close unrounded vowel i-high front open, a-mid front unrounded. Arabic writing starts from right to left and without capitalization. Most of the letters in Arabic are cursive (connected) ${ }^{?}$ ) (This part belongs to which)

Noticeably, the schwa vowel occurs in Arabic especially in unstressed syllables in the first syllable in the name /'Mubarak/ or /'Mohammed/. Which is the cause of FL learners problems with schwa vowel, because in English it represents by many different letters for example: <ous $>$ in gracious /greifəs/ or thorough $/ \theta \wedge$ rə/. These different vowel letters in contrast to Arabic orthographic conventions, stand evident for FL learners confusion, substitution or replacement. 
Vowels' Contrastive areas

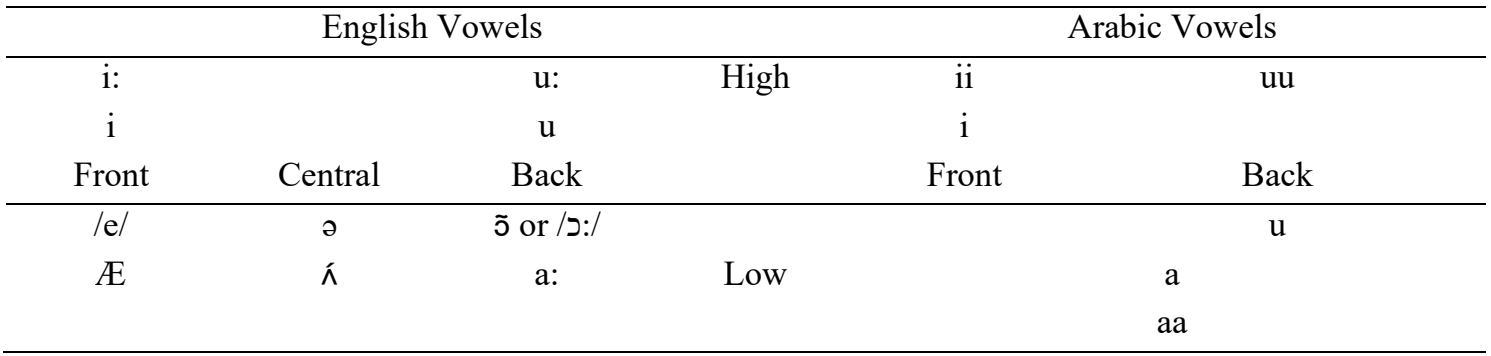

\section{Data Analysis and Discussion}

Students' results for the first test

\subsection{Vowels and Diphthongs}

These results stand evident that there is a quite difference between English and Arabic vowels. The reason for why most of Sudanese learners of English have phonological problems in the areas of segmental sounds (vowels, diphthongs). They pronounce sounds according to their spelling. For example $<_{0}>$ in body - was- wall or $<\mathrm{a}>$ in heart- cart- far or $<\mathrm{u}>$ in spoon- soon- moon or schwa -n possible- particular- forget.

The results clarify that these learners produce incorrect pronunciation

From students' test and interview questions in the area of vowels and diphthongs, the researcher reaches to the following points:

a. /i/ and /e/ are normally confused so students produce $<$ bid for $>$ bed -will and well - till- tell- thin-then -

b. $/ \mathrm{a} /$ and $/ \Lambda$ are also substituted by each other that learners utter but for bat- some- come - custom- tonguethorough- exchanged to $<0>$

c. /o/ and / $/$ :/ are replaced by one another, students use /o/ for both sounds or mixed with $<\mathrm{u}>\operatorname{good}-$ God

d. /æ/ and /a:/ are also confused, students tend to replace them as /ka:t/ for /kæt/ and /kæ/ for /ka:/. Or even with long (o) in wall - hall- call - tall.

e. /o/ and /ou/ are mixed by FL beginners as $<\mathrm{o}$, for, ow $>$ as in /go/ for /gəu/ or long $<\mathrm{o}>$ law- draw- in addition to the spelling areas of cow- how

f. The schwa vowel areas do not exist in Arabic. It is an area of common mistake as inearn- burn - word - bird /bə:d/ to be berid, or particular being pronounced /particular/ for /pə'tikjələ/, apply, carrot - correct -

g. /ei/ and /ou/ as diphthongs are usually pronounced short as in hope which is pronounced /hop/ for /həup/. (like for like /laik/). Or (cry, krei for /krai/ As an area of confusion between sounds and spellings. In fact, all vowels cause problems for FL learners. Especially when they're compared with Arabic ones. Thus, all students produce incorrect sounds. The fact that the tables for results reflects their lower performance. From the first test's results, it is found that the two groups are similar. There is no statistical differences between both of them when they applied the same practice, which reflects their improvement in the posttest.

This shows that Most of the Sudanese learners of English have phonological problems in the segmental areas. In particular the areas that is different than Arabic.

\section{Recommendations}

1) This study finds out that:

The organization of LI, L2 are different. Therefore in order to master English pronunciation, learners have to practice the habit of looking up words into dictionaries to be sure of how to pronounce it perfectly.

2) The teacher is the backbone of the learning process. That the teacher's role affects the teaching /learning process to a high degree. So, effective (happy) learning is very important. These types of difficulties need motivation and creativity of natural environments.

3) Listening to recorded native speakers' discourse.

4) English intensive drills in the areas of vowels, diphthongs, consonants, clusters, stress and intonation lead learners toward correct pronunciation.

5) Intensive sound discrimination drills.

6) The computer improves teaching pronunciation and arise students' motivation towards learning English. 
7) Continuous training, Seminars in addition to demonstration lessons help graduate teachers to be qualified. The following key words are especially important for helping to become familiar with the challenging of short and long vowels.

\begin{tabular}{lcc}
\hline short $a$ & cat & $\mathrm{c}-\underline{\mathrm{a}}-\mathrm{t}$ \\
shorte & $\mathrm{bed}$ & $\mathrm{b}-\underline{\mathrm{e}}-\mathrm{d}$ \\
short $i$ & sit & $\mathrm{s}-\underline{\mathrm{i}}-\mathrm{t}$ \\
shorto & top & $\mathrm{t}-\underline{\mathrm{o}}-\mathrm{p}$ \\
short $u$ & sun & $\mathrm{s}-\underline{\mathrm{u}}-\mathrm{n}$
\end{tabular}

Additionally, when a vowel is pronounced with a short vowel sound, it may be followed by two consonants. Both consonants are not necessary for short vowel identification purposes, but do often offer an additional clue that the particular sound in that instance is a short vowel sound.

\begin{tabular}{lll}
\hline short $e$ & Bend & end \\
short $i$ & Sịck & $\underline{\text { it }}$ \\
short $o$ & Lock & $\underline{\text { on }}$ \\
short $u$ & Such & $\underline{\text { us }}$
\end{tabular}

Pronunciation respelling systems for English have been developed primarily for use in dictionaries. They are used there because it is not possible to predict with certainty the sound of a written English word from its spelling or the spelling of a spoken English word from its sound. So readers look up an unfamiliar word in a dictionary may find, on seeing the pronunciation respelling, that the word is in fact already known to them orally. By the same token, those who hear an unfamiliar spoken word may see several possible matches in a dictionary and must rely on the pronunciation respellings to find the correct match.

In most dictionaries, the pronunciation symbols used to show how words are pronounced are adapted from the IPA (International Phonetic Alphabet). If we know how to interpret the symbols, many of which are familiar letters of the alphabet, a dictionary can be a great help for learning pronunciation as well as for understanding meaning.

\section{References}

Alkhuli, M. A. (2004). An Introduction to Linguistics. Dar Swaileh: Alfalah.

Allwright, D., \& Hanks, J. (2009). The Developing Language Learning: An Introduction to Exploratory Practice. Palgrave Mac Baker, A. Cambridge: Cambridge University Press. https://doi.org/10.1057/9780230233690

Al-Samawi, A. (2000). An Introduction to Research Techniques. In Linguistics and Leterature - Sana'a University, Yemen.

Attahir, A. (1986). Manhajul Bahth Al-Adabi (Arabic) (Litrary Research Nethod). Al-Maktabah Al- A'lameyah.

Bloom, P. (2002). Mindreading communication and learning of names for things. Mind \& language, 17(1-12),

37-54. Cambridge: Cambridge University Press. https://doi.org/10.1111/1468-0017.00188

Clark, E. (2003). First language Acquisition. Cambridge: Cambridge University Press.

Ehsan Mohammed Abdelgadir, \& VSV Laxmi Ramana. (2017). A Handbook on "Introduction to Phonetics \& Phonology": For Arabic students.

Ehsan Mohammed Abdelgadir. (2010). Phonological Problems Affecting The Teaching/Learning process of ELT, A Sudanese case Study of Secondary Schools

Ehsan Mohammed Abdelgadir. (2019). Challenges of Teaching Communication To Arabic Students. English Language Teaching, 12(4), 179. https://doi.org/10.5539/elt.v12n4p179

\section{Copyrights}

Copyright for this article is retained by the author(s), with first publication rights granted to the journal.

This is an open-access article distributed under the terms and conditions of the Creative Commons Attribution license (http://creativecommons.org/licenses/by/4.0/). 